Kaygl, 18(1)/2019: 58-74.

Araştırma Makalesi | Research Article

Makale Geliş | Received: 07.09.2018

Makale Kabul | Accepted: 30.12.2018

Yayın Tarihi | Publication Date: 15.03.2019

DOI: $10.20981 /$ kaygi.505717

Diler Ezgi TARHAN

Doktora Öğrencisi | PhD Candidate İstanbul Üniversitesi, Edebiyat Fakültesi, Felsefe Bölümü, İstanbul, TR Istanbul University, Faculty of Letters, Department of Philosophy, İstanbul, TR

ORCID: 0000-0003-3208-9962

dilertarhan@gmail.com

\title{
Husserl'in Transzendental Fenomenolojisinde Zaman Bilincinin Kuruluşu ve Bilincin Süreç Kipleri Üzerine
}

Öz

$\mathrm{Bu}$ makaleyle yapılmak istenen Edmund Husserl'in transzendental fenomenolojisi bağlamında apriori zamansallığın süreç kiplerini analiz etmek ve Husserl'in şimdiye dek zaman bilinci hakkında ortaya konulan görüşlerini açık kılmaktır. Bu amaçla "şimdi algısı"na dair temel izlenim aşamasından hareketle, bilincin geçmişe dair iki aşaması olan "Retention" ve "Reproduktion" aşamalarıla birlikte, bilincin geleceğe dair kipleri olan "Protention" ve "beklenti (Erwartung)" aşamaları açıklandıktan sonra, zaman nesnesinin aktüel algısından söz edilecek ve bilinç fenomenlerinin nasıl olup da zamansal nesneler olarak kuruldukları açıklanacaktır. Akabinde kuruluşu (Konstitution) önceleyen mutlak bilinç akışı olarak transzendental mutlağa değinilecek ve Husserl'in zamanı kuran bilinç fenomenlerini, zamanda kurulan bilinç fenomenlerinden ayrı tutmasının nedenleri açıklanacaktır.

Anahtar Kelimeler: Bilinç Fenomenleri, Konstitution, Retention, Reproduktion, Protention.

\section{On Consciousness's Process Modes and Constitution of Time Consciousness in Husserl's Transzendental Phenomenology}

\begin{abstract}
What is intended to do in this report is to analyse the process modes of apriori temporality in the context of Edmund Husserl's transzendental phenomenology and to make it clear the views of Husserl's on the temporal consciousness that put out there till now. For that purpose with this act from basic impression phase about perception of present and together with the two modes of consciousness about the past, the Retention and Reproduktion phases, and after the disclosure of Protention and expectation (Erwartung) stages, which are the modes of consciousness for the future, the actual perception of time objects will be mentioned and how the consciousness phenomenas are constituted as temporal objects will be explained. After that, transzendental absolute will be mentioned as the absolute consciousness flow which introduces Constitution and the reasons why Husserl distinguishes the consciousness phenomena that constitutes time from the consciousness phenomena that were constituted in time will be explained.
\end{abstract}

Keywords: Consciousness's Phenomena, Constitution, Retention, Reproduction, Protention. 
Husserl, her ne kadar fenomenolojik analiz için başat konumda olduğunu ileri sürdüğü "zaman kurucu bilinç" konusuna Ideen adlı yapıtının ilk cildinde değinmişse de Husserl'in bu konuyu esas ele aldığı eser; İçsel Zaman Bilincinin Fenomenolojisi Üzerine olarak kabul edilmektedir. 1904 ile 1910 yılları arasında Heidegger tarafından derlenip yayınlanan bu eserde Husserl zamansallığın bilinç yaşantıları açısından oynadığ1 rolü şu şekilde açıklamıştır: "Zamansallık kavramının yaşantılar için ifade ettiği öz nitelik, yalnızca her yaşantıya ait genel bir forma sahip olmayıp ayrıca da yaşantıları diğer yaşantılarla birbirine bağlayan zorunlu bir forma işaret etmektedir. Husserl'e göre her yaşantı belli bir süreç içinde ortaya çıkmakta ve bu süreç zarfinda, sonsuz bir süreklilik arz eden süreçler dizisine dahil olmaktadır. Bu bağlamda Husserl'e göre yaşantıların belli bir zaman diliminde ortaya çıkmasının bir getirisi olarak kendini sonsuz biçimde gerçekleştiren bir zaman ufkunun varlığı kaçınılmazdır. Ayrıca Husserl'e göre bu zaman ufku, sonsuz bir yaşantılar akışını içermektedir (Husserl 1992: 182)." Nitekim tüm psişik fenomenler, yani bilince içkin tüm yaşantılar, zaman mefhumuyla yapılandırılmıştır; bu nedenle de bunların tamamı bilincin zamansallığı hükmü altındadır.

Öte yandan Husserl'in zaman konusundaki fenomenolojik tahlillerini İçsel Zaman Bilincinin Fenomenolojisi Üzerine adlı eser döneminde bahsettiklerine indirgemek elbette haksızlık olur. Zira "Husserl'in, hayatı boyunca zaman fenomenolojisiyle ilgilendiği gerçeği, neredeyse 30 yılı aşan bir döneme işaret eder. $\mathrm{Bu}$ ilgi ve uğraşın tarihsel biçimlenişi, başlangıcın kökensel fragmanlarıyla beraber ortaya çıkan ve yaygın fenomenoloji literatüründe sıkça sözü edilen kısaca şu üç dönemin tasviri sayesinde gösterilir:

1. Dönem: Husserl'in Göttingen Üniversitesi'nde 1904/05 güz sömestri tarihli Bilgi Teorisinin ve Fenomenolojinin Ana Parçaları dersini içeren ve zaman bilincinin yapısını işleyen bu metin, Edith Stein'ın düzeltmeleriyle beraber Martin Heidegger tarafindan, Jahrbuch für Philosophie undphänomenologische Forschung adlı yıllık (IX. cilt) için 1928 yılında yayıma hazırlandı. Bu edisyon, aynı zamanda 1910 yılına dek olan zaman fenomenolojisi konulu metinlerini kapsar. 1893-1919 yılları arasındaki 
zaman teorisi metinleri de eklenerek Husserliana'nın X. cildinde yine Vorlesungen zur Phänomenologie des inneren Zeitbewusstseins başlığıla Rudolf Boehm tarafından (1966) yayımlandı. Bu eserde en geniş hatlarıyla zamanın kökeni sorusuna ilişkin ilk gelişim kademelerinin tasvir edildiği fenomenolojik bir metnin önceleyen orijinalliği söz konusudur (Husserl 2015).

2. Dönem: Husserl'in 1917 kışını ve 1918 baharını geçirdiği Bernau dönemi olarak bilinmekle birlikte, Husserl bu dönemde zaman sorularına yoğunlaşarak zamana ilişkin ilk metinleri daha da deşer. Kendi zamansızlığındaki mutlak bilincin tahlili, asli zaman alanı, yeniden hatırlama, fantezi, transzendental bilincin kendiliğindenliği, zamansal bölünmez/tekilleşmeyle olan ilişkilerini inceler. Leuven'deki Husserl Arşivi'nde 'L' işaretli bu metinler, 2001 yılında, R. Bernet [Leuven] ve çalışma arkadaşları tarafından Husserliana'nın XXXIII cildi olarak yayımlandi.

3. Dönem: 1927-1933 yıllarını kapsayan son evre olarak bu dönemde Husserl, yeniden zaman sorunu, bölünmez/tekil zaman bilincinin sorunları, bu sorunların süjeler arası tarihle ve yaşam bağlamıyla ilişkileri gibi konuları işlerken, zaman fenomenolojisinden tarih fenomenolojisine geçişi icra etmeyi hedefledi. Leuven'de 'C' işaretli bu el yazmaları, gerçi kısmen de olsa Husserl'in süjeler-arasılık fenomenolojisi bağlamında Husserliana'nın XV. cildinde yer buldu ama 2006 yılında Husserliana'nın Materialien kısmının VIII. cildinde Späte Texte über Zeitkonstitution (1929-1924) Die C-Manuskripte başlığıyla D. Lohmar [Köln] tarafından yayımlandı" (Keskin 2016: 6566).

Husserl'in fenomenolojik zaman görüşüne gelinince; Husserl'e göre “fenomenolojik zaman" (1992: 180) "tüm yaşantıların birlik içinde olduğu bir formdur" (1992: 180). Başı ve sonu belli olmayan bu yaşantıları birarada tutan zaman formu olarak "fenomenolojik zaman”; “nesnel, yani kozmik zamandan” (Husserl 1980: 369) ayırt edilmelidir. Çünkü Husserl’e göre “özdeşlik birimlerinin kuruluşunun kaynağında içsel zaman bilinci bulunmaktadır" (Marx 1987: 53) ki bu bilinç kozmik zamandan ziyade fenomenolojik zamanı kuran bilinçtir. Dolayısıyla Husserl fenomenolojik zaman görüşüyle yalnızca bilince içkin zaman nesneleri olarak yaşantıların kuruluşunu değil, ayrıca zamansal olarak yapılanmış bilincin kendi kuruluşunu da açıklamış olmaktadır. Husserl'in "süreçlerin sonsuz kesintisizliği” (Keskin 2016: 72) olarak tanımladığı, bilince içkin "fenomenolojik zaman”, içsel zaman bilinci iken "kozmik zaman” ise Husserl'in "mekân ve doğa zamanı" (Keskin 2016: 72) olarak tanımladığı nesnel zamandır. Husserl'e göre bu nesnel zaman, bilince aşkındır ve "Reproduktion" aşamasında özdeşlikle birlikte kurulmaktadır. 
Husserl, sürekli değişmekte olan yaşantılar akışı içinde, fenomenlerin nasıl olup da özlerini yitirmediklerini, yani tüm bu değişim sürecine rağmen fenomenlerin nasıl olup da kendileriyle aynı kalabildiklerini, "noema - noesis" ayrımı üzerinden açıklamaktadır. Husserl'in bu ayrımla tam olarak neye işaret ettiğinin daha iyi anlaşılabilmesi için Husserl'den başka, Gurwitsch ve Beils'ın görüşlerinden de yardım alınabilir. Zira Gurwitsch ile Beils, Husserl'i "noema - noesis" anlayışı bakımından destekleyen ve tamamlayan düşünürlerdir. Kaldı ki Husserl gibi Gurwitsch de “fenomenolojik zamanda var olan 'noesis'ler (Gurwitsch 1964: 423) ile "zamansiz olmaları bakımından ideal yapılara işaret eden 'noema'ları (Gurwitsch 1964: 423) birbirinden ayırmış ve bu ayrımdan hareketle noetik edimi, “fenomenolojik zamansallık yasalarına bağlı olan bilinç” (Gurwitsch 1964: 423) olarak tanımlamıştır. Ayrıca Gurwitsche'e göre noetik bilinç, zaman süreğeninde birbirini takip eden ânları birleştirerek edimlere ait aşamalar haline getirmektedir (1964: 424). Öte yandan "noematik edim" ise "noesis"ler akışı içinde bulunan herhangi bir nesneselliğin (Gegenständlichkeit) "konstitute" edilmesinde etkin rol oynamaktadır. Zaten "noetik içkin bilinç akışının esas önemi de bu değişkenlik ve çeşitliliğin zaman akışı içindeki sürekliliğinden ileri gelmektedir. Öte yandan transzendental nesnenin kuruluşu, sürelerden ânlara geçilmesini hızlandırmaktadır: Belli bir "Sachverhalt", kendi verilişinin değişken yapısı içinde ancak kendisiyle özdeş kaldığı takdirde süreklilik gösterebilmektedir" (Beils 1987: 39).

Şimdi Husserl'in apriori nitelikteki zaman yapısını nasıl yapılandırdığını açacak olursak: Husserl'e göre apriori zaman yapısı, "süreç kiplerinden" (1980: 389) oluşmaktadır. Birbirleri arasında geçişlilik özelliği bulunan bu süreç kipleri arasındaki birlik ise bilinç akışının sürekliliğini kurmaktadır (1980: 389). Bilinç akışı sürekliliğinin kurulmasında etkin rol oynayan süreç kiplerinin ilk aşaması "şimdi” aşamasıdır. Husserl, "şimdi" aşamasını "temel izlenim aşaması" olarak görmekte ve "içkin nesnenin var olmaya başladığg süreç kipi” (1980: 389) olarak tanımlamaktadır. Yani bilince içkin olan nesnelerin ilk kez "temel bir izlenim" (1980: 390) ile karşılaşmaları, bu aşamada gerçekleşmektedir. 
Temel izlenimler "fenomenolojik açıdan mutlak orjinallikteki yaşantıları temsil eden temel yaşantılardır. [...] Dikkatle bakılırsa onların sürekli akış halindeki mutlak orijinal bir aşama olarak 'yaşanan şimdiki ân'ı kendi somutlukları içinde içerdikleri görülmektedir" (Husserl 1992: 167). Şimdiye ait bu ânlar, birer "şey algısı" olmaları bakımından, anı ya da fantezi gibi temel yaşantılardan ayrılmaktadır. Husserl temel yaşantıları, "geçmişte kalmışlığın sürekli gelişen sürekliliği”" (1980: 389) olarak temel izlenimlere indirgemekte ve bu indirgeme sayesinde de belleğe dayalı bir bilinç aşamasına geçmektedir. Dolayısıyla bir nesnenin aktüel bilinci sürekli değişmek zorundadir.

Öte yandan temel izlenim aşamasını izleyen ikinci aşamaya gelecek olursak; Husserl bu aşamayı "Retention" aşaması olarak adlandırmaktadır. "Retention" yani "birincil düzey hatırlama aşaması"nda ise -ses fenomeni gibi- izlenime dayalı temel yaşantılar bilinçte tutulmaktadır" (1980: 396). Bu nedenle "Retention" aşamasındaki bellek, "az önce olanın bilinci" (1980: 392) olarak kabul edilmekte, ancak bellek aşamaları arasındaki sürekliliğin birliği açısından da "konstitute" edilmiş, içkin bilinç olarak görülmektedir. Başka bir deyişle Husserl, "bellek aşaması” adını verdiği "Retention" aşamasını "bir edim olmaktan ziyade, gelip geçmiş bir aşamanın anlık bilinci” (1980: 472) olarak görmekte ve bu aşamayı "birincil hatırlama aşaması" olarak nitelendirmektedir.

“Temel izlenim aşaması" ile "birincil düzey hatırlama aşaması"ndan sonra gelen "ikincil düzey hatırlama aşaması" ise Husserl tarafından "Reproduktion" aşaması olarak adlandırılmaktadır. $\mathrm{Bu}$ aşamada bilinç, artık yaşantıları tutmaktan ziyade yeniden üretme faaliyetine girişmektedir. Yani birincil ve ikincil düzey hatırlama aşamalarının ikisi de bilincin iki geçmiş kipine tekabül etmelerine karşın, yeniden üretim aşaması olarak "Reproduktion" (ikincil düzey hatırlama) (Husserl 1980: 390) aşamasının, bellek aşaması olarak "Retention" (birincil düzey hatırlama) aşamasından belirgin bir farkı bulunmaktadır: Bellek yani "Retention" aşamasında izlenime dayalı bilinç, "aktüel anlamda var olanın şimdisi" (1980: 390) olarak önce "sürekli belleğe, sonra da buradan 
belleğin belleğine geçerken; yeniden hatırlama aşamasında yani "Reproduktion"da ise temel izlenimler, zaman bakımından geçmişe dönüktür ve hatırlanan geçmişe dönerek tüm algıyı tekrar etmektedir” (Bernet, Kern \& Marbach 1989: 100). Dolayısıyla bilincin bir yeniden üretim faaliyetini gerçekleştirebilmesi için bellek şarttır. Başka bir deyişle "Retention” aşaması, "Reproduktion" aşamasını öncelemektedir.

Husserl'e göre bellek sayesinde "geçmişe dönülmesi her ne kadar mümkün olsa da bellek, geçmiş aşamaları kendisine nesne kılmaktan uzaktır. Zaten Husserl'e göre ben ancak geçmiş aşamalar kendi kontrolüm altında olduklarında şimdiki ânı yaşabilir; bellek aracılığıyla onu diğerine ekleyebilir ve bir sonraki ân için hazırlıklı olabilirim. Dolayısıyla geçmiş bir yaşantının benim kontrolüm altında olması demek, benim hatırlama edimi içinde kalarak ya da refleksiyona başvurarak bakışımı ona yönlendirebileceğim” (1980: 472) anlamına gelmektedir. Fakat burada özellikle belirtilmesi gereken şey şudur ki: Bellek ile refleksif yeniden üretim, yalnızca aralarındaki zamanla ilişkiler bakımından değil, ayrıca apaçıklık ve kesinlik bakımından da birbirlerinden farklıdır. Nitekim "belleğimde kendisinin bilincinde olduğum şey [...] mutlak kesinlikte" (1980: 407) olmasına rağmen, "Reproduktion" aşamasındaki “yeniden üretimden yanılgılar doğması halen mümkündür” (1980: 407). Özetle izlenimin apaçıklığının bellekte bulunmasına ve belleğin dolaysız izlenimler aracılığıyla şimdiki zamanı "konstitute etmesine" (1980: 398) karşın; bilinç, yeniden üretim aşamasında, daha uzak zaman dilimlerinde tutulan nesnelere yönelmektedir. Örneğin dün duyduğum herhangi bir şarkının melodisini bugün hatırlamam, "Reproduktion" sayesinde mümkün olmaktadır.

"Retention" ve "Reproduktion" aşamalarından sonra, şimdi de bilinç akışının sürekliliğini sağlayan diğer "Konstitution” aşamalarını açacak olursak: Husserl'e göre bilincin iki geçmiş kipi olan "Retention" ve "Reproduktion" aşamalarını, bilincin geleceğe dair iki kipi olan "Protention" ile "beklenti (Erwartung)" aşamaları izlemektedir. "Protention" aşamasında bilinç, zamansal nesnelerin yaşantı akışına yönelmekte; "Protention" kipi de aynen "Retention" kipinde olduğu gibi, izlenimlere 
dayalı olarak kurulmaktadır. Geleceğe dair bilinç kiplerinden diğeri olan 'beklenti' (Erwartung) aşaması ise "içkin içeriğin "konstitute edilen aşamalarından ziyade, gelecekteki içkin içeriği şimdide canlandırmaya yöneliktir” (1980: 437). Kısaca "Protention" aşaması, geçmiş bilinç kiplerinden "Retention” aşamasının; "beklenti” aşaması ise geçmiş bilinç kiplerinden "Reproduktion” aşamasının gelecek bilinç kipi olarak görülebilir. Böylece Husserl, "Protention" aşamasında ilk izlenimlerle birlikte birincil düzey hatırlamalarımızın bir süreklilik oluşturduklarını, yani bu "kuyruklu yıldız silsilesinin" (1980: 395) izlenimleri çevreleyen bir zaman avlusu kurduğunu ileri sürmektedir. Husserl'in "belleğin belleği” olarak adlandırdığı bu "kuyruklu yıldız silsilesi” (Kometenschweif), örneğin az önce işitilmiş bir sesin ya da melodinin bilinç tarafından gelecekte de sürdürülen izidir. Yani az önce duyduğumuz fakat şimdi susmuş olan bir ses ya da melodinin kulağımızda çınlamayı sürdürmesi ya da bilinçte bir sürekliliğe sahip olabilmesi, bilincimizde, aynen kuyruk yıldızın kaydıktan sonra ardında bıraktığg iz gibi bir iz bırakmaktadır. Bu nedenle Husserl'e göre bir zaman nesnesinin aktüel algısı, yalnızca şimdideki algılar toplamına değil, ayrıca da bir “geçmiş ve gelecek görüsüne” (1980: 396-401) karş1lık düşmektedir.

Böylece Husserl bilginin fenomenolojik koşullarına geri dönmekle hem 'transzendental Ego'ya hem de onun saf yaşantılarına ulaşmış olmaktadır. Husserl'e göre redüksiyonlar yoluyla kazanılan transzendental bilinç analizi, doğrudan zamansallıkla ilgilidir, çünkü transzendental verilmişlikler olarak saf yaşantılar, zamansal yapılarına göre kategorize edilmektedir. Husserl bu konuyu İçsel Zaman Bilincinin Fenomenolojisi Üzerine Dersler (Husserl 1980) adlı metninde daha detaylı biçimde şu soru üzerinden ele almıştır: Bilinç fenomenlerinin zamansal nesneler olarak kuruluşları (Konstitution) nasıl gerçekleşmektedir? Bu soru şüphesiz, şu sorunun da yanıtlanmasını da beraberinde getirir: Transzendental Ego, kendisini zamansal olarak nasıl "konstitute" etmektedir? Husserl işte bu iki soruya zaman kipleri analizi üzerinden verdiğgi yanıtlarla hem bilinç fenomenlerinin hem de transzendental Ben'in nasıl "konstitute" edildiğini ortaya koymuştur. Husserl'e göre kozmik zamanın, içsel zaman bilincinde nasıl "konstitute" edildiği sorusu, ancak bilincin apriorisi ile yanıtlanabilir. 
Bilinç, öznel ve nesnel zamanı kuran ancak kendisi zamansal olmayan apriori mutlaktır. Kozmik zaman, bilince aşkın; fenomenolojik zaman ise kendisini fenomenal bütünlüğü içinde veren, bilince içkin zamandır. Başka bir deyişle fenomenolojik zaman, sürelerin sonsuz kesintisizliğine tekabül eden içsel zamandır. Husserl bu analizleriyle, kendisine gelininceye dek ortaya konulmuş tüm çalışmaların önüne geçmiştir. Yalnızca Aristotelesçi ve Agustinusçu zaman algısının değil, ayrıca da Franz Brentano, Carl Stumpf ve William Stern gibi isimler tarafından ortaya konulan zaman bilinci görüşlerinin ötesine geçmiştir. Husserl'in yapmak istediği, daha ziyade, zaman görüşleri bakımından Agustinus ile Aristoteles arasında bir köprü kurmaktır. Öte yandan Husserl'in zaman bilinci konusundaki görüşleri, kendisinden sonra gelen Bernau, Merleau-Ponty, Levinas, Ricoeur, Derrida, Waldenfels ve Schmitz gibi isimleri etkileyerek bu isimlerin zaman kurucu bilinç konusuna farklı pencerelerden bakmalarına esin kaynağı olmuştur.

Ideen I ve İçsel Zaman Bilincinin Fenomenolojisi Üzerine Dersler adlı kitaplarında da vurguladığı üzere, Husserl'e göre nihayetinde transzendental Ego'nun bile gidip kendisine dayandığı en son neden, mutlak bilinç akışıdır. Redüksiyonlar sonucunda elde edilen bu transzendental mutlak, aslında nihaî bir son değil; aksine kendini sürekli geliştirerek "konstitute eden" (Husserl 1992: 182) bir mutlaktır. Değişime ve gelişmeye açık yapıdaki bu transzendental mutlak, Husserl açısından "tüm “Konstitutation'ları önceleyen, mutlak bilinç akışından başkası değildir” (1980: 428). Başka bir deyişle bilinç akışının zamansal nesneleri, ancak bu mutlak bilinç akışı sayesinde kurulabilmektedir. Fakat şunun özellikle belirtilmesi gerekir ki Husserl, zamanı "konstitute" eden bilinç fenomenleri ile zamanda "konstitute" edilen bilinç fenomenleri arasında önemli bir ayrım yapmaktadır: Zamanı "konstitute" eden apaçık fenomenler "bireysel süreçler değildir ve bireysel süreçlerin yüklemleri, bunlara dahil olamaz" (1980: 429). Öte yandan "bilinç akışının fenomenal olarak konstitute edildiği bilinç akışı aşamaları, bu konstitute edilen aşamalarla bir tutulamaz" (1980: 437). Dolayısıyla zamanı "konstitute" eden akış, zamanda kurulan bir nesne olmaktan ziyade, zamansızlıkla karakterize edilen "mutlak öznelliktir" (1980: 429). Nitekim Husserl bu 
durumu şöyle izah etmektedir: "Bu akışın zamanı yoktur, ' $\mathrm{O}$ ' zaman dahilinde değildir" (1980: 479). Görüldüğü gibi Husserl’e göre “esas akışta süre bulunmaz” (1980: 466). Bundan dolayı Husserl açısından fenomenolojik zaman, zamanda kurulan bir nesne olmaktan ziyade "mutlak zamansız bilinçte konstitute edilen" (1980: 464) içsel zamandir.

Bilinç akışının nesnelleştirilemez bir şey olarak saptanması, mutlak öznellikle birlikte "bilginin imkânı" problemini doğurmuştur. Husserl'e göre gerçekten de burada söz konusu olan ne algının ne de refleksiyonun imkânıdır; aksine tam olarak bilginin imkânıdır. Zaten "tüm bunların yok olduğu bilinci ben tekrar algılayamam. Çünkü onu algılayabilmem mümkün olsaydı da bu yeni algılanmış olan bilinç yine zamanda kurulmuş; dolayısıyla da konstitute edilmiş bir bilince işaret ederdi ki bu da benim bu konstitute edici akıştan nasıl haberdar olduğum sorusunu ortaya çıkarırdı” (Husserl 1980: 463). Husserl'e göre bahsi geçen "konstitute edici akış" şimdiki zamana, bilinç sayesinde sahip olmakta ve şimdiki zamana ulaşmakla da aslında kendini "konstitute" etmektedir. "İçkin ve zaman kurucu bilincin akışı, kendi varlığını kendinde içerdiğinden bilincin bu akış içinde aynı zamanda algılanabilir olması gerekmektedir. Yani akış fenomeni ikinci bir akışı gerektirmemekte, aksine bir fenomen olarak kendi kendini konstitute etmektedir" (Husserl 1980: 436). Husserl'e göre akış fenomeni, şimdiki zamanın nesnellik-öncesi bilincinde yer almakta ve zamansal bir nesneye indirgenemez olmakla; sanki de refleksiyon öncesi bir varlıkmış gibi kendini gerçekleştirmektedir.

İçsel Zaman Bilincinin Fenomenolojisi Üzerine Dersler'de değinilen transzendental öznelliğin kendini zamansal olarak "konstitute" etmesinden kaynaklanan sorun, Husserl fenomenolojisinin geç döneminin temel sorunlarından biri haline gelmiştir. Husserl'in "Konstitutation” sorunu hakkındaki görüşlerinde yer alan temel kavram ise "canlı şimdiki zaman" (Held 1966: VII) kavramıdır. Husserl bu kavramı analiz etmekle, "artık onun ötesinde daha fazla mantıksal refleksiyona dayalı herhangi bir ifadenin bulunamadı̆̆g” (Held 1966: 68) bir "şimdiki zaman fenomeni”ne ulaşmış olmaktadır. Husserl'in "kendinde saf şimdiki zaman" (Held, 1966: 68) olarak 
adlandırdığı bu zaman, bütün refleksiyonları önceleyen ve onların gerçekleşebilmesini mümkün kılan zamandır. Husserl "kendinde zaman" veya "refleksiyon öncesi saf şimdiki zaman" adını verdiği bu zamanın özünü, "durağanlığın ve akışın birliği”" (Held 1966: 75) olarak betimlemektedir. Refleksiyon sürekli bir akış halinde olup "Ben" olarak "Ego", bu akış içinde sürekli ilerlemesine rağmen; şimdiki zaman, tüm refleksiyonları önceleyen durağan bir an olarak akışın "kendisiyle bütünleşmektedir" (Held 1966: 81).

"Refleksiyon öncesi şimdiki zamanın kendisi" (Held 1966: 82-97) olarak tanımlanan bu zaman tüm refleksiyonlar için gerekli olmasına rağmen refleksiyon, durağan da olsa akış halinde de olsa hiçbir surette "saf zamanı önceleyen bir 'Ben'in şimdisini kavrayamamaktadır" (Held 1966: 89). Bu nedenle tüm refleksiyonlarda fenomenolojik açıdan orjinal bir biçimde farkına varılan 'Ben', 'şimdi' ile her karşılaşmasında, dünyevileşmiş bir nesne haline gelmektedir. Başka bir deyişle 'Ben', zamanı önceleyen canlı 'şimdi' ile her karşılaşmasında, "nesnelleşmiş, somutlaşmış, dünyevileşmiş ve zamansallaşmış" (Held 1966: 90) olmakta ve bunun sonucu olarak da "akış halindeki zamansal bir nesneye" (Held 1966: 89) dönüşmektedir. Burada zamansal nitelikteki temel edilgin akışın varlığıyla ilgili olarak bu akışın ne türden bir varoluşa sahip olduğu sorusu ortaya çıkar ki bu soru birçok düşünür tarafından "sorulmaması gereken; hatta sorulması mümkün olmayan bir soru" (Held 1966: 103) olarak görülmektedir. Çünkü "temel edilginlik, akış halindeki ön-varoluş ve önzamansallık gibi konularla ilgili ifadeler, içerikçe boştur” (Held 1966: 104). Tam da bu nedenden ötürü Husserl'in akışın varoluş biçimi hakkında öne sürdüğü düşünceler, eleştirilerin odak noktası olmuştur.

Nitekim “zaman fenomenolojisinin tarihteki etkilerine bakıldığında, Husserl'in neredeyse karşı kutbu, hemen yanı başındaki eski dostu ve halefi, Heidegger'dir. Heidegger, yönelimsel yapıyla Husserl'in esas adımı attı̆̆ını söylemesine rağmen, zaman sorununu -işte zamanı içkin bir şey, yani süjedeki içkinlik olarak gören- eski anlayışla çözmeye çalıştğııı ve bundan dolayı içsel zaman bilinci başlığını derslerinde 
kullandığını ifade eder. Tüm zaman bilincini bir sırf duyuş verisine ilişkin bilgiye dayandırmakla Husserl'i eleştirir. [...] Zaman kavramının tarihi, zamanın keşfedilişinin tarihidir ki bu, varolanın varlığına ilişkin sorunun tarihidir. Tarihten hareketle zamanı anlatmaya çalışan Heidegger zamanı, Husserlci duyusallıktan uzak bir şekilde, aşkınlık olarak anlar ve bilince uygun aşkınlaştıran tasavvur faaliyetinin yerine fenomenolojik bir ontolojiyi dikip zamanın metafizik özünü soruşturur. Bu noktada Husserl'in Mantık Araştırmaları'ndaki yönelimsellik problematiğini zaman bilincine dair dersleriyle daha deştiğini söyleyip zamana ilişkin bilincin kökensel anlamda zamanın kendisi olduğunu vurgular ki bunu zamansallık (Zeitlichkeit) olarak niteler: 'Zamanın özü zamansaldır' derken Heidegger, şunu 1srarla öne sürer ki, zaman var değil'dir’, aksine zaman, zamansallaşır. Ona göre, varlık ve zaman birbirine aittir ki zaman, varlığın vukû bulmasıyla aynılaştırılmalıdır. Zamanın sübjektif kavramının karşısına varoluşsal zaman tecrübesini koyar. Zaman, süjenin dışındadır, kendi ölümünde ve hiç olmasındadır. Oaradalık (Dasein), varlığını kaygıda, ölüm olanağında, varlık anlayışında bulur” (Keskin 2016: 72-73).

Görüldüğü üzere Husserl, kendisinden zamansal akışın varoluşu konusunda yorumda bulunmaktan kaçınması beklenirken "doğal akışın deneyimlenmesi ve ifade edilmesinin, bir ön-varoluşla mümkün olmamasından ötürü” (Held 1966: 103), “Ben'in her daim 'anonim bir Ben' olarak kalmak zorunda olduğunu” (Brand 1955: 64) söylemiş olması bakımından eleştirilmiştir. Çünkü Heidegger başta olmak üzere Husserl'i eleştiren düşünürler, her ne kadar "canlı şimdiki zamanın temel bir fenomene sahip olduğunu" (Held 1966: 115) kabul etseler de onun bir "olgu olarak kabul edilmesi” (Held 1966: 115) fikrine şiddetle karşı çıkmaktadır. Dolayısıyla Husserl'in refleksiyonu önceleyen, yani ön-reflektif nitelikteki canlı şimdiki-zaman tasarısında ortaya çıkan "paradoks, refleksiyonla çözülememektedir" (Held 1966: 118). Ancak Husserl'in canlı şimdiki zamanı "geriye dönük dedüktif bir çıkarım” (Held 1966: 118) olarak temellendirmesi bakımından eleştirildiğini söylemekle birlikte, onu bu konuda desteklemiş düşünürlerin de olduğunu belirtmek gerekir. Nitekim bu düşünürlere göre yapılması gereken gerçekten de 'transzendental Ben'in son temellerine varıncaya dek 
geriye doğru gitmektir. Husserl'i bu konuda destekleyen düşünürlerin başında gelen Seebohm, Husserl'in 'transzendental Ben'i temel öznellik olarak görmesinde ve onun deneyimlenemez olduğunu iddia etmiş olmasında (1962: 66) hiçbir sakınca görmemektedir. Seebohm’a göre transzendental fenomenoloji, mutlak alanda kaldığ 1 sürece her transzendental yol, mutlak olanı gerçekleştirecektir. Fakat kendinde mutlak, Seebohm açısından hâlâ bir sır olarak kalmayı sürdürmektedir. Seebohm'a göre kendinde mutlak öznellik, "dolaysız bir biçimde elde edilmesi mümkün olmayan" (1962: 161) bir “içre oluş" (1962: 164) olarak tanımlanabilir.

Husserl "canlı şimdiki zaman”ın bilinç deneyimi ile onda içkin olarak bulunan bilinç etkinliklerini incelemiş ve "canlı şimdiki zaman"1n transzendental yaşantıların kuruluşunda olmazsa olmaz olduğunu söylemiştir. Ayrıca “canlı şimdiki zaman” tüm refleksif edimleri öncelemesine rağmen kendisi refleksiyon aracılığıyla kavranamamaktadır. Çünkü Husserl, geç dönem fenomenolojisindeki "canlı şimdiki zaman" görüşünü, deneyimin nesnesi olamayacak anonim bir "olgu olarak şimdiki zaman" görüşü üzerinde şekillendirmiştir. İşte Husserl'in felsefesinin geç dönemlerine dek analiz ettiği ve nihayetinde refleksiyon ile ön-refleksiyon kavramları 1şığında açıkladığı bu görüş, hem bilinç yapısının bilimsel kesinlikte aydınlatılmasına dair fenomenolojik niyetten hem de canlı şimdiki zamanın olgu bağlılaşımları (Sachverhalte) aracılığıyla açıklanması çabasından vazgeçildiği anlamına gelmektedir. Nitekim Husserl'in geç döneminde savunduğu görüşler uyarınca olgu bağlılaşımları (Sachverhalte) hakkında söyleyebileceğimiz tek şey bunların "var olup olmadıkları hakkında bir şeyin söylenemeyeceği” (Seebohm 1962: 66) ve hatta var olup olmadıklarının bile şüpheli olduğudur. Görüldüğü üzere Husserl geç dönem çalışmalarında, insan bilinci ile yaşantısından başka, ayrıca da genel olarak refleksiyon koşullarını araştırmıştır. Fakat bütün bu zaman ve zaman bilinci analizlerine rağmen Husserl fenomenolojisinin "canlı şimdiki zaman”ın varlığını gerekçelendirmek bakımından eksik kaldığı ve bu konuda tatmin edici bir bilinç kipi ortaya koyamadığ 1 düşünülmektedir. Bu nedenle de Husserl fenomenolojisinde transzendental yaşantılar ile 
transzendental refleksiyonun dolaysız yaşantısının tespit edilmesine dair transzendental kuramın yetersiz olduğu kanaati hâkimdir.

Özetle metinde, Husserl fenomenolojisinin geç döneminde yoğun olarak tartışılan zaman kurucu bilinç, bilinç yaşantıları, zaman ufku, akış fenomeni, zaman türleri, "noetik - noematik süreç" ayrımı, "Konstitution” süreci, bilincin süreç kipleri, transzendental öznellik ve refleksiyon konuları üzerinde durularak bilincin geçmiş ve gelecek kipleri açıklanmıştır. Buna göre belli bir süreç içinde ortaya çıkan bilince içkin yaşantılar, zaman tarafından "konstitute" edilerek bilincin akış aşamalarını ortaya koymaktadır. Zamanda "konstitute" edilen bu fenomenlerden farklı olarak zamanı "konstitute" eden bilinç fenomenleri ise apaçık ve zamansız bir mutlak öznellikten başkası değildir. Dolayısıyla Husserl bilinç akışıyla, zamanda kurulan bir nesneyi kast etmemektedir. O'na göre zaten bilincin zamanda "konstitute" edilmesi mümkün olsaydı da bizim bundan nasıl haberimiz olacağı sorusu yanıtsız kalmaktadır. $\mathrm{Bu}$ nedenle Husserl hem nesnellik öncesi hem de refleksiyon öncesi içkin fenomen olarak zaman kurucu akışın kendi kendini "konstitute" eden transzendental bir öznellik olduğunu düşünmektedir. Husserl'e göre bu akış fenomeni, durağanlıkla biraraya gelerek tüm refleksiyonları önceleyen bir zamanı kurmaktadır ki Husserl bu zamanı, "kendinde şimdiki zaman" veya "saf şimdiki zaman" olarak adlandırmaktadır. Husserl'in geç dönem fenomenolojisi işte bu canlı şimdiki zamanın, tüm refleksif edimlerin zorunlu önkoşulu olarak tayin edilmesine rağmen, kendisinin refleksiyon aracılığıyla kavranamaz olması noktasında düğümlenmektedir. Bu düğümden hareketle deneyimin nesnesi olarak görülemeyecek olan bu zaman hakkında nasıl olup da "geriye dönük dedüktif bir çıkarım” yakıştırmasının yapıldığı muamma olarak kalmaktadır. Tam da bu nedenle Husserl, refleksiyonlarda fenomenolojik olarak kendisiyle ilgili farkındalığa 
Diler Ezgi TARHAN, "Husserl’in Transzendental Fenomenolojisinde Zaman Bilincinin Kuruluşu ve Bilincin Süreç Kipleri Üzerine," Kaygı, 18(1)/2019: 58-74.

vardığımız "anonim Ben”in şimdiki zaman ile karşılaşınca zamansal bir nesneye dönüşmesi noktasındaki görüşünün paradoksal olması sebebiyle eleştirilmektedir.

Husserl, fenomenolojik zaman ile nesnel zaman arasındaki farkı, "noema noesis" ayrımı üzerinden temellendirmiştir. Bu ayrım uyarınca fenomenolojik zaman, bilince içkin zaman nesnelerini kuran "içsel zaman bilinci” olarak tanımlanırken; nesnel zaman ise zamansal olarak yapılanmış bilincin kendisini kuran "kozmik zaman" olarak tanımlanmaktadır. "Noesis'ler" fenomenolojik zamana içkin bilinç akışı zemininde tanımlanırken; "noema"ların ise zamansız ve ideal yapıda oldukları, dolayısıyla da kozmik zaman bağlamında oldukları vurgulanmaktadır. Başka bir deyişle "noetik edim", fenomenolojik zaman yasalarına bağlıyken; noematik edim ise "noesis akışı" içindeki doğrulukları kuran anlamlar olarak ifade edilmektedir. Husserl fenomenolojik kozmik zaman ayrımından sonra transzendental nesnenin kuruluşuna paralel biçimde süreden ân'a geçilmesini, apriori bir zamana geçiş olarak görmektedir. Bu apriori zaman ise beş farklı süreç kipinden oluşmaktadır. Bilincin süreç kiplerini kısaca şu aşamalar üzerinden özetleyebiliriz:

\section{1- Şimdi Aşaması (Temel İzlenim Aşaması)}

İçkin nesnenin var olmaya başladığı bu aşamada bilinç temel izlenimlere dayalı olarak şimdinin zamanını kurmaktadır. Temel yaşantılar, temel izlenimlere indirgenir indirgenmez bilinç "temel izlenim aşaması"ndan "birincil düzey hatırlama aşaması"na geçmektedir.

\section{2- Bilincin Geçmişe Dair Süreç Kipleri:}

\section{1) Birincil Düzey Hatırlama Aşaması (Bellek / Retention Aşaması)}

"Konstitute" edilmiş bilincin bu aşamasında bellek, dolaysız izlenimlere bağlı olarak yaşantıları hafızada tutmaktadır. Bu aşamadaki içkin bilinç, geçmiş bir ân'ın bilinci olarak ortaya çıkmaktadır.

\section{2) İkincil Düzey Hatırlama Aşaması (Yeniden Üretim / Reproduktion Aşaması)}

Hatırlama edimi veya refleksiyon yoluyla geçmişe dönerek yaşantıları yeniden ürettiğimiz bu aşama, bellek aşamasındaki mutlak apaçıklığa ulaşmış değildir. Daha açık bir deyişle bellek aşamasında söz konusu olan zaman, nesnel yapıda ve temel izlenimler, mutlaktır; yeniden üretim aşamasında ise zaman, fenomenolojik yapıda ve temel izlenimler, muğlaktır. $\mathrm{Bu}$ aşamada bilinç, uzak zaman dilimindeki nesnelere yöneldiğinden apaçık 
bir kesinlikten söz edilememekte ve bu nedenle de "ikincil düzey hatırlama" aşamasındaki bilinç bizi yanıltabilmektedir.

\section{3- Bilincin Geleceğe Dair Süreç Kipleri:}

\section{1) Protention Aşaması}

Bilinç aynen "Retention" aşamasında olduğu gibi bu aşamada da temel izlenimlere dayalı biçimde, zamansal nesnelerin yaşantı akışına yönelmektedir. "Protention" aşaması, bilincin geçmişe dair süreç kiplerinden olan "Retention" aşamasının gelecek kipi olarak kabul edilebilir. Husserl zaman nesnesinin etkin algısının hem geçmiş ve gelecek görülerine hem de şimdiki zamandaki algılar toplamına bağlı olarak gerçekleşeceğini savunmaktadir.

\section{2) Beklenti (Erwartung) Aşaması}

Bilincin geçmişe dair süreç kiplerinden olan "Reproduktion" aşamasının gelecek kipi olarak görülebilecek bu aşamada bilinç, gelecekteki içkin içeriği şimdide canlandırmaktadır.

Husserl bilincin süreç kiplerini analiz etmekle hem bilinç fenomenlerinin hem de transzendental Ben'in zamansal olarak nasıl "konstitute" edildiklerini açıklamış olmaktadır. Bahsi geçen geçmişe ve geleceğe dair kiplerle birlikte bilinç, bu kiplerle eşzamanlı olarak aktüel olana yönelmekte; geçmiş - şimdi ve gelecek zamanı birarada tutmaya çalışırken süreye dönüşmektedir.

Husserl'e göre redüksiyonlara uğratılan transzendental bilincin saf yaşantıları ancak zamansallıkla ilgileri içinde analiz edilebilir. İşte tüm bu redüksiyonları önceleyen mutlak bilinç akışı, transzendental Ego'nun bile kendisine dayandığı nihai nedendir. Husserl, değişime açık nitelikteki bu transzendental mutlağın varoluş biçimini açıklamaya çalışırken bilincin analiziyle ilgili çeşitli sorunlar ortaya çıkmış ve Husserl, erken döneminde maruz kaldığı psikolojizm ve solipsizm tehlikesiyle geç dönem fenomenolojisinde de hesaplaşmak zorunda kalmıştır. Nitekim zamanı kuran bilincin kendisinin zaman dışı olduğu iddiası, kendisi nesnel olmayan bir bilincin nasıl olup da nesnel zamanı ortaya koyabildiği sorusunu doğurmuş ve bu soruya verilen yanıtlar çeşitli tartışmalara yol açmıştır. Ancak biz makalemizin konusu gereği burada yalnızca Husserl'in Ideen I ve Içsel Zaman Bilincinin Fenomenolojisi Üzerine kitapları bağlamında öne sürdüğü zaman ve bilinç kuramının temel dayanaklarını vererek 

ve Bilincin Süreç Kipleri Üzerine,” Kaygı, 18(1)/2019: 58-74.

Husserl'in transzendental fenomenolojisi bağlamında analiz ettiği apriori zamansallığa ait süreç kiplerini ortaya koymayı amaçladığımızdan, Husserl'in zaman analizinin yol açtığı paradoksları ele almayı, başka bir makale konusu olarak görmekteyiz. Bundan dolayı da bu makalemizde, konumuz gereği, Husserl'de zaman bilincinin kuruluşu ve bilincin süreç kiplerini açıklayarak bunların ilgi içinde oldukları temel kavram ve konuları birincil kaynaklardan faydalanarak aydınlatmış bulunmaktayız. 


\section{KAYNAKÇA}

BEILS, Karl Bernhard (1987). Transzendenz und Zeitbewußtsein. Zur Grenzproblematik des transzendental-phänomenologischen Idealismus, Bonn: Bouvier Verlag Herbert Grundmann.

BERNET, Rudolf, KERN, Iso \& Eduard MARBACH (1989). Edmund Husserl. Darstellung seines Denkens, Hamburg: Felix Meiner Verlag.

BRAND, Gerd (1955). Welt, Ich und Zeit. Nach unveröffentlichten Manuskripten Edmund Husserls, Den Haag: Martinus Nijhoff Verlag.

GURWITSCH, Aron (1964). Der Begriff des Bewußtseins bei Kant und Husserl, Kantstudien - Band 55, Köln: Kölner Universitäts-Verlag.

HELD, Klaus (1966). Lebendige Gegenwart. Die Frage nach der Seinsweise des transzendentalen Ich bei Edmund Husserl, Den Haag: Martinus Nijhoff Verlag.

HUSSERL, Edmund (1992). Ideen zu einer reinen Phänomenologie und phänomenologischen Philosophie. Erstes Buch: Allgemeine Einführung in die reine Phänomenologie, Gesammelte Schriften - Band V, Elisabeth Ströker, Hamburg: Felix Meiner Verlag.

HUSSERL, Edmund (1980). Vorlesungen zur Phänomenologie des inneren Zeitbewußtseins, ed. Martin Heidegger, II. Bask1, Tübingen: Max Niemeyer Verlag.

KESKIN, Mesut (2016). Zaman Fenomenolojisinin Sifir Noktasına Doğru, ETHOS: Felsefe ve Toplumsal Bilimlerde Diyaloglar, 9(1): 63-76.

MARX, Werner (1987). Die Phänomenologie Edmund Husserls. Eine Einführung, München: Verlag Fink.

SEEBOHM, Thomas (1962). Die Bedingungen der Möglichkeit der Transzendental-Philosophie. Edmund Husserls transzendental-phänomenologischer Ansatz, Bonn: H. Bouvier u. CO. ANDERSON. 